\title{
Efek Pemberian Jus Semangka Terhadap Penurunan Tekanan Darah
}

\author{
'Zainal Munir, ${ }^{2}$ Muhajaroh \\ ${ }^{1}$ Fakultas Kesehatan Universitas Nurul Jadid (UNUJA), Probolinggo,Indonesia \\ ${ }^{2}$ Rumah Sakit Bina Sehat, Jember,Indonesia \\ *email: zainalmunirnj@gmail.com
}

\begin{abstract}
Abstrak
Kata Kunci : hipertensi; jus semangka; tekanan darah

Key Words: hypertension; watermelon juice; blood pressure

Hipertensi adalah penyakit degeneratif yang semakin sering dijumpai dimasyarakat. Hipertensi juga nempunyai hubungan erat dengan resiko kejadian penyakit kardiovaskuler, dengan tekanan darah yang ebih tinggi, maka akan lebih besar pula kemungkinan terjadinya penyakit ginjal, stroke, serangan jantung, dan gagal jantung. Tujuan penelitian adalah Menganalisa adanya pengaruh pemberian jus semangka terhadap perubahan tekanan darah sistolik dan diastolik pada penderita hipertensi di Dusun Tanjung Lor Jesa Karang Anyar Paiton Probolinggo. Desain dalam penelitian ini menggunakan eksperimen semu iquasy experiment design), dengan perancangan pretest-posttest with control group. Teknik yang digunakan ialah teknik purposive sampling dengan jumlah populasi 35 individu yang mengalami hipertensi dan sampel yang digunakan adalah 30 individu sebagai responden dengan penyakit hipertensi, Penelitian ini dilakukan 10 hari dan responden diukur tekanan darahnya pre dan post intervensi, observasi tekanan darah selama 3 hari dengan pre perlakuan. 7 hari dengan perlakuan waktu pengukuran 2 jam :setelah perlakuan, penelitian ini dilakukan untuk mengetahui perbedaan tekanan darah sistolik dan diastolik pre perlakuan dengan setelah perlakuan. Hasil uji analisa statistik menunjukkan ada pengaruh jemberian jus semangka terhadap penurunan tekanan darah sistolik dan diastolik dengan $p=\langle 0.05(0.010)$. Kesimpulan dari penelitian ini adalah ada perbedaan tekanan darah pada penderita hipertensi setelah jemberian jus semangka terhadap penurunan tekanan darah sistolik dan diastolik. Berdasarkan hasil jenelitian ini diharapkan memberikan manfaat dengan pemanfaatan tanaman obat keluarga untuk nengurangi pengobatan kimiawi bagi masyarakat dan merupakan salah satu solusi bagi perawatan penderita hipertensi.

Info Artikel:
\end{abstract}

Tanggal dikirim: 10

April 2019

Tanggal direvisi

25 April 2019

Tanggal diterima:

29 April 2019

DOI Artikel:

10.33862/citradeli

ma.v3i1.49

Halaman: 10 - 14

\begin{abstract}
Hypertension is a degenerative disease increasingly found in community. Hypertension is also closely linked to the risk of cardiovascular disease events, with higher blood pressure, the greater will be the likelihood of kidney disease, stroke, heart attack, and heart failure. The research objective is to Analyze the effect of watermelon juice to changes in systolic and diastolic blood pressure in patients with hypertension in Dusun Tanjung Karang Recent Lor Paiton Probolinggo. Design in this study using a quasi-experimental (Quasy experiment design), with a pretest-posttest design with control group. The technique used is purposive sampling technique with a population of 35 individuals who have hypertension and the sample used for the study were 30 individuals with hypertension, The research was carried out 10 days and their blood pressure measured respondents' pre and post intervention, blood pressure observed for 3 days with pre treatment. 7 days with a treatment time of measurement 2 hours after treatment, this study was conducted to determine differences in systolic and diastolic blood pressure pre treated with after treatment. Statistical analysis of test results showed no effect of watermelon juice to decrease systolic and diastolic blood pressure by $p=>0.05(0.010)$. The conclusion from this study is that there are differences in blood pressure in hypertensive patients after administration of watermelon juice to decrease systolic and diastolic blood pressure. Based on the results of this study, it is expected to provide benefits by utilizing family medicinal plants to reduce chemical treatment for the community and is one of the solutions for the care of hypertensive patients.
\end{abstract}

\section{PENDAHULUAN}

Hipertensi atau darah tinggi merupakan penyakit kelainan jantung dan pembuluh darah yang ditandai dengan peningkatan tekanan darah. Tidak ada tandatanda yang dapat dirasakan pasien. Darah tinggi seakan menjadi ancaman karena dengan tiba-tiba seseorang divonis menderita hipertensi. Penyakit hipertensi yang menduduki peringkat pertama penyebab stroke dan jantung (Dewi, S \& Familia, D. 2010). Dapat diketahui 9 dari 10 orang yang menderita hipertensi tidak dapat diidentifikasi penyebab penyakitnya. Itulah sebabnya hipertensi dijuluki sebagai "pembunuh diam-diam" (silent killer) (Saraswati, S. 2009). 
Pengobatan hipertensi secara garis besar dibagi menjadi dua, yaitu farmakologi dan non farmakologi. Salah satu cara untuk mengontrol hipertensi adalah dengan terapi non farmakologi, seperti diet rendah garam/kolesterol, menciptakan suasana rileks, melakukan senam atau olahraga selama 30-45 menit selama 3-4 kali seminggu, berhenti merokok dan kurangi konsumsi alkohol, terapi herbal/ tradisional dengan menggunakan buah dan sayur, diantaranya tanaman dan buah-buahan yang mampu menurunkan tekanan darah adalah belimbing manis, mentimun, seledri, bawang putih, mengkudu, jeruk nipis, tomat, rosella, daun salam, semangka, daun tempuyung, kumis kucing. Dari beberapa terapi non farmakologi yang dapat menurunkan tekanan darah, disini peneliti tertarik menggunakan semangka sebagai bahan penelitian yang dapat menurunkan tekanan darah (Saraswati, S. 2009).

Penelitian sebelumnya yang melakukan intervensi dengan pemberian Jus Mentimun pada penederita Hipertensi bahwasannya Kalium yang terkandung pada mentimun dengan dapat menurunkan Hipertensi. Dimana peneliti melakukan pengukuran setelah pemberian jus Mentimun dengan kurun waktu 2, 6 dan 9 Jam setelah intervensi. Ternyata adanya penurunan yang signifikan pada 2 jam setelah pemberian jus Mentimun (Kusnul Z \& Munir Z. 2012)

Semangka mengandung vitamin $\mathrm{C}$ dan provitamin A. Semangka Bermanfaat sebagai anti alergi, penurunan kadar kolesterol darah, dan mencegah serangan jantung (M. Aphrodita, 2010). Kandungan kalori dan kalium dalam buah semangka sangat rendah sehingga semangka dapat berfungsi sebagai diuretik. semangka mengandung sejumlah nutrisi seperti serat, likopen, vitamin A, dan potasium. Studi Florida State University menunjukkan bahwa semangka juga mengandung asam amino $L$ citrulline/L-arginine, yang memberi efek menurunkan tekanan darah tinggi. Pada sebuah penelitian terapi jus semangka yang diberikan dalam dosis 100 gram perhari dapat menurunkan tekanan darah sistolik dan diastolik sebesar 4,4 dan 2,5 $\mathrm{mmHg}$ pada penderita hipertensi, sedangkan pada orang normal dapat menurunkan tekanan darah sebesar 1,8 dan 1,0 mmHg. Pada pemberian 100 gram buah semangka yang dijus dapat dijadikan $100 \mathrm{ml}$ jus untuk satu kali pemberian terapi (Saraswati, Sylvia, 2009)

\section{METODE}

Penelitian ini merupakan penelitian eksperimental untuk mengetahui pengaruh pemberian jus semangka terhadap perubahan tekanan darah. Desain dalam penelitian ini menggunakan eksperimen semu (quasy experiment design), dengan perancangan pretest-posttest with control group (Nursalam, 2011). Penelitian ini dilaksanakan di Desa Karanganyar Paiton Probolinggo dengan melibatkan 30 responden yang terbagi 15 kelompok kontrol dan 15 kelompok intervensi, responden pada penelitian ini adalah responden yang menderita hipertensi stadium 1 tanpa komplikasi penyakit atau penyakit lainnya (Diabetes mellitus) dan responden mengalami peningkatan tekanan darah secara mendadak.

Instrumen penelitian yang digunakan untuk mengetahui perubahan tekanan darah pada penelitian ini berbentuk lembar observasi yang didalamnya berisi biodata responden, tekanan darah responden sebelum dan setelah diberikan perlakuan, timbangan kue, gelas ukur, blender dan tensimeter. Instrument yang digunakan dalam penelitian ini adalah observasi terstruktur. Observasi terstruktur ialah pengukuran observasi secara terstruktur berbeda dari jenis yang tidak terstruktur yaitu peneliti secara cermat mendefinisikan apa yang akan diobservasi melalui suatu perencanaan matang. Peneliti tidak hanya mengobservasi fakta-fakta yang ada pada subjek, tetapi lebih didasarkan pada perencanaan penelitian yang sudah disusun sesuai pengelompokannya, pencatatan, dan pemberian kode hal-hal yang sudah ditetapkan.

\section{HASIL DAN PEMBAHASAN}

Pemberian jus semangka ini diberikan 1 kali sehari (pada jam 09.00) pemberian jus semangka ini dengan berat 100 gram dengan tambahan air mineral $50 \mathrm{ml}$ tanpa gula, kemudian dihancurkan dengan menggunakan blender. Semangka yang digunakan adalah semangka yang berwarna merah dan berbiji. Dengan menggunakan timbangan kue untuk menentukan berat semangka yang diberikan. Pengukuran tekanan darah setelah diberi intervensi/ perlakuan dilakukan satu kali sehari pada jam 11.00 (2 jam setelah perlakuan). Pengukuran tekanan darah pada individu dilakukan dengan menggunakan tensimeter air raksa. Data yang telah diperoleh selanjutnya ditabulasi, menentukan ratarata untuk setiap hasil pengukuran dan disajikan dalam bentuk tabel.

\section{Data Umum}

Table 1 Karakteristik Responden Berdasarkan Usia

\begin{tabular}{c|c|c|c|c|c}
\hline No & Usia & $\begin{array}{c}\text { Kelompok } \\
\text { Kontrol }\end{array}$ & $\begin{array}{c}\text { Kelompok } \\
\text { Eksperimen }\end{array}$ & Jumlah & Presentase \\
\hline 1 & $30-35$ & 3 & 2 & 5 & $10 \%$ \\
\hline
\end{tabular}




\begin{tabular}{c|c|c|c|c|c}
\hline 2 & $36-40$ & 4 & 3 & 7 & $25 \%$ \\
\hline 3 & $41-45$ & 5 & 7 & 12 & $45 \%$ \\
\hline & $46-60$ & 3 & 3 & 6 & 20 \\
\hline & Jumlah & 15 & 15 & 30 & $100 \%$ \\
\hline
\end{tabular}

Tabel 1 menunjukkan bahwa usia responden paling dominan adalah pada usia antara 41-45 tahun yaitu sebanyak 12 orang (45\%). Sedangkan responden yang berusia 30-35 tahun yaitu sebanyak 5 orang $(10 \%)$.

Tabel 2 Karakteristik Responden Berdasarkan Tingkat Pendidikan

\begin{tabular}{c|c|c|c|c|c}
\hline No & $\begin{array}{c}\text { Tingkat } \\
\text { Pendidikan }\end{array}$ & $\begin{array}{c}\text { Kelompok } \\
\text { Kontrol }\end{array}$ & $\begin{array}{c}\text { Kelompok } \\
\text { Eksperimen }\end{array}$ & Jumlah & Presentase \\
\hline 1 & TS & 6 & 9 & 15 & $50 \%$ \\
\hline 2 & SD & 7 & 5 & 12 & $40 \%$ \\
\hline 3 & SLTP & 2 & 1 & 3 & $10 \%$ \\
\hline & Jumlah & 15 & 15 & 30 & $100 \%$ \\
\hline
\end{tabular}

Tabel 2 menunjukkan bahwa tingkat pendidikan responden yang paling dominan adalah tidak sekolah yaitu sebanyak 15 orang (50\%), sedangkan tingkat SLTP sebanyak 3 orang (10\%).

Tabel 3 Karakteristik Responden Berdasarkan Jenis Kelamin

\begin{tabular}{c|c|c|c|c|c}
\hline No & Jenis Kelamin & $\begin{array}{c}\text { Kelompok } \\
\text { Kontrol }\end{array}$ & $\begin{array}{c}\text { Kelompok } \\
\text { Eksperimen }\end{array}$ & Jumlah & Presentase \\
\hline 1 & Laki-Laki & 4 & 2 & 6 & 20 \\
\hline 2 & Perempuan & 11 & 13 & 24 & 80 \\
\hline & Jumlah & & & & \\
\hline
\end{tabular}

Tabel 3 menunjukkan bahwa responden yang berjenis kelamin perempuan paling dominan yaitu sebanyak 24 orang $(80 \%)$, sedangkan yang berjenis kelamin laki-laki berjumlah 6 orang (20\%).

\section{Data Khusus}

Karakteristik penurunan tekanan darah kelompok kontrol awal (pretest) dan akhir (posttest).

Tabel 4 karakteristik penurunan tekanan darah kelompok kontrol awal (pretest) dan akhir (posttest).

\begin{tabular}{c|c|c|c}
\hline Hari & Pretest & Posttest & P.Value \\
\hline Ke-1 & $1.27-+0.458$ & $1.47-+0.516$ & 0.257 \\
\hline $\mathrm{Ke}-2$ & $1.07-+0.258$ & $1.20-+0.414$ & 0.157 \\
\hline $\mathrm{Ke}-3$ & $1.00-+0.000$ & $1.00-+0.000$ & 1.000 \\
\hline $\mathrm{Ke}-4$ & $1.07-+0.258$ & $1.13-+0.352$ & 0.317 \\
\hline $\mathrm{Ke}-5$ & $1.00-+0.000$ & $1.07-+0.258$ & 0.317 \\
\hline $\mathrm{Ke}-6$ & $1.00-+0.000$ & $1.07-+0.258$ & 0.317 \\
\hline $\mathrm{Ke}-7$ & $1.27-+0.458$ & $1.47-+0.516$ & 0.257 \\
\hline
\end{tabular}

Dari hasil tabel 4 diatas dapat disimpulkan bahwa mulai hari ke-1 sampai ke-7 penelitian, dengan menggunakan uji statistik menunjukkan bahwa tidak terjadi penurunan tekanan darah secara signifikan pada kelompok kontrol, hal ini dapat dibuktikan dengan hasil nilai $p>0.05$.

Karakteristik penurunan tekanan darah kelompok eksperimen awal (pretest) dan akhir (posttest).

Tabel 5. Karakteristik penurunan tekanan darah kelompok eksperimen awal (pretest) dan akhir (posttest).

\begin{tabular}{c|c|c|c}
\hline Hari & Pretest & Posttest & P.Value \\
\hline Ke-1 & $1.47-+0.516$ & $1.27-+0.458$ & 0.083 \\
\hline Ke-2 & $1.40-+0.507$ & $1.27-+0.458$ & 0.157 \\
\hline Ke-3 & $1.13-+0.352$ & $1.20-+0.414$ & 0.317 \\
\hline Ke-4 & $1.07-+0.458$ & $1.07-+0.458$ & 1.000 \\
\hline Ke-5 & $0.87-+0.352$ & $0.73-+0.458$ & 0.157 \\
\hline Ke-6 & $0.67-+0.488$ & $0.53-+0.516$ & 0.024 \\
\hline Ke-7 & $0.47-+0.516$ & $0.00-+0.000$ & 0.008 \\
\hline
\end{tabular}


Dari hasil tabel 5.5 diatas pada hari ke-1 menunjukkan adanya penurunan tekanan darah yang signifikan dengan nilai $\mathrm{p}<0.05$, sedangkan pada hari berikutnya tidak terjadi penurunan, hal ini mungkin disebabkan karena banyaknya variabel penggaggu dalam penelitian ini, mugkin bisa disebabkan karena faktor stress dan kebiasaan pola makan responden yang masih mengkonsumsi garam atau makanan yang terasa asin.

\section{Pembahasan}

a. Karakteristik penurunan tekanan darah kelompok kontrol awal (pretest) dan akhir (posttest).

Dari hasil penelitian untuk kelompok kontrol disini diharapkan tidak mengalami penurunan, tetapi pada penelitian ini terjadi penurunan pada hari ke-2, Hal ini mungkin disebabkan karena tingkat pendidikan responden yang lebih tinggi dan pola istirahat responden yang baik. Akan tetapi setelah disimpulkan hasil penelitian mulai dari hari-1 sampai dengan hari ke-7 kelompok kontrol dalam uji statistik tidak menunjukkan hasil yang signifikan yaitu nilai Asymp.sig 0.257 pada hari ke-7 peneltian, berarti $\mathrm{p}>0.05$, maka kesimpulannya H0 diterima HA ditolak yang berarti tidak terdapat perbedaan antara pretest dan posttest

\section{b. Karakteristik penurunan tekanan darah kelompok eksperimen awal (pretest) dan akhir (posttest).}

Dari hasil penelitian untuk kelompok eksperimen yang diberikan perlakuan berupa jus semangka selama 7 hari didapatkan tidak terjadi penurunan pada hari ke-2, 3, 4 dan 5. Hal ini mungkin disebabkan karena responden yang sedang diteliti mengalami stress atau kurangnya waktu istirahat responden. Karena tekanan darah bisa berubah secara tiba-tiba, maka setelah pemeriksaan pada hari ke-7 terjadi penurunan baik sistolik maupun diastolik.

Klasifikasi penurunan tekanan darah menurut grade ringan dan sedang dalam penelitian ini tidak terjadi penurunan tekanan darah, disebabkan terlalu jauhnya rentang antara hipertensi sedang sampai ke hipertensi ringan, Karena kemampuan dari jus semangka yang diberikan dalam dosis $100 \mathrm{cc}$ hanya mampu menurunkan 4,4 mmHg tekanan darah sistolik dan 2,5 $\mathrm{mmHg}$ tekanan darah diastolik. Akan tetapi apabila dihitung secara nominal dari hasil pengukuran terdapat penurunan tekanan darah selama 7 hari penelitian. Hasil uji statistik antara hari ke-1 hingga hari ke-7 didapatkan nilai P.Value sebesar 0.008 berarti $\mathrm{p}<0.05$, maka kesimpulannya $\mathrm{H} 0$ ditolak HA diterima yang berarti terdapat perbedaan antara pretest dan posttest

Penurunan tekanan darah sistolik dan diastolik pada penderita hipertensi karena kandungan kalium (potassium) yang terdapat pada semangka yang 147 $\mathrm{mg} / 100 \mathrm{gram}$ atau $260 \mathrm{mmol}$. Semangka mempunyai kemampuan membantu menurunkan tekanan darah karena kandungan kalium (potasium), magnesium, dan fosfor dalam semangka efektif dan mampu mengobati hipertensi. Selain itu, semangka juga bersifat diuretik karena kandungan airnya yang tinggi sehingga membantu menurunkan tekanan darah (Aphrodita, M. 2010). Sehingga kalium (potasium) membantu mengatur saraf perifer dan sentral yang mempengaruhi tekanan darah. Mengkonsusmsi kalium yang banyak akan meningkatkan konsentrasinya di dalam cairan intraseluler sehingga cenderung menarik cairan dari bagian ekstraseluler dan menurunkan tekanan darah (Almatsier, S. 2001).

Peneilitian ini diperkuat oleh penelitianpenelitian klinis lain yang memperhatikan bahwa pemberian suplemen kalium dapat menurunkan tekanan darah dengan suplementasi diet kalium 60-120 $\mathrm{mmol} / \mathrm{hari}$ dapat menurunkan tekanan darah sistolik dan diastolik 4,4 dan 2,5 mmHg pada penderita hipertensi dan 1,8 serta $1,0 \mathrm{mmHg}$ pada orang normal (Saraswati, Sylvia, 2009).

\section{c. Analisa Perbedaan Tekanan Darah Sistolik Dan Diastolik Kelompok Eksperimen Dan Kelompok Kontrol}

Dalam uji Mann-Whitney Test $\alpha=0,05$, bila nilai $\mathrm{p}<0,1$ dan $\alpha>0,05$ atau $\mathrm{p}>0,1$ dan $\alpha>0,05$. Berdasarkan hasil uji SPSS 16.0 dalam penelitian ini menghasilkan nilai sistolik rata-rata perubahan sebelum dan sesudah pada observasi 2 jam setelah perlakuan serta dengan rata-rata setiap hari observasi yang akan dikumpulkan pada hasil rata-rata pada selama 7 hari perlakuan penelitian dalam hitungan perhari, akhirnya digabung dari semua hasil penelitian pre perlakuan dan post perlakuan. Dari hasil 
spss pada kolom Asymp Sig terlihat bahwa nilai probabilitas adalah $0.000<\alpha=0,05$. Maka keputusan yang diambil adalah $\mathrm{HO}$ ditolak. Interpretasi: H0 ditolak dan memberikan kesimpulan secara statistik pada penelitian ini ada perbedaan tekanan darah sisitolik dan diastolik pada penderita hipertensi di Dusun Tanjung Lor Desa Karang Anyar sebelum dan sesudah diberi jus semangka.

Perbedaan tekanan darah pre perlakuan dan setelah perlakuan pada penelitian ini yang dikarenakan adanya asupan kalium sebesar 100 gram yang diberikan berupa jus semangka. Sehingga secara biologis terjadi peningkatan konsentrasi di dalam cairan intraseluler sehingga cenderung menarik cairan ekstraseluler dan akan terjadi penurunan tekanan darah sistolik dan diastolik. Penurunan tekanan darah sistolik dan diastolik dengan perlakuan jus semangka hanya bersifat sementara dan sangat bervariasi perubahan yang didapat. Sebenarnya hipertensi pada penelitian ini bisa mencapai pada tekanan yang normal. Dengan tidak terjaganya pola hidup yang terdapat di Dusun Tanjung Lor yang banyak makanan yang beresiko akan meningkatkan kembali tekanan darah tersebut. Sehingga terdapat hasil yang sangat bervariasi. Jus semangka memberikan kecepatan waktu penurunan tekanan darah sistolik dan diastolik dengan catatan menjaga pola hidup yang akan menjadi pencetus terjadinya hipertensi.

\section{SIMPULAN}

Pemberian intervensi jus semangka terhadap penderita hipertensi dengan 100 gram semangka terdapat penurunan signifikan pada kelompok intervensi dan tidak ada perubahan yang berarti pada kelompok kontrol. Hal ini menunjukkan adanya efektifitas pemberian jus semangka pada penderita hipertensi pada stadium 1 dengan nilai P.Value $=<0.05(0.010)$.

\section{DAFTAR PUSTAKA}

Almatsier, S. 2001. Prinsip Dasar Ilmu Gizi, Gramedia Pustaka Utama, Jakarta.

Aphrodita, M. 2010. Terapi Jus Buah Dan Sayur,

Katahati, Jogjakarta.
Corwin, E. 2009. Buku Saku Patofisiologi, Buku Kedokteran EGC, Jakarta.

Dewi, S \& Familia, D. 2010. Hidup Bahagia Dengan Hipertensi, A plus, Jogjakarta.

Figueroa A, 2010. Effects of Watermelon Supplementation on Aortic Blood Pressure and Wave Reflection in Individuals With Prehypertension, American Journal of Hypertension. Diakses pada 20 oktober 2010.

Gemilang, J. 2012. 1001 Aneka Buah \& Sejuta Khasiatnya Ampuh Mengatasi Beragam Penyakit, Araska, Yogyakarta.

Lisia, 2004 Pengaruh Pemberian Jus Semangka (Citrullus Vulgaris, Schard) Terhadap Ekskresi Urin Tikus (Rattus Norvegicus) Strain Wistar.

Pdf(http://health.groups.yahoo.com/group/dok ter_umum/message/ 4075.htm, diakses 21 Februari 2005).

Lusita, S. 2011. Aneka Resep Jus Sehat \& Lezat Untuk Panjang Umur, Araska, Yogyakarta.

Mansjoer, 2001. Kapita Selekta Kedokteran, Media Aesculapis Fakultas Kedokteran UI, Jakarta.

Maulana, M. 2008. Penyakit Jantung Pengertian, Penanganan, Dan Pengobatan, Kata Hati, Jogjakarta.

Notoatmodjo, S. 2010. Metodologi Penelitian

Kesehatan, Rineka Cipta, Jakarta.

Nursalam, 2011. Konsep Dan Penerapan Metodologi Penelitian Ilmu Keperawatan Pedoman Skripsi, Tesis, Dan Instrument Penelitian Keperawatan, Salemba Medika, Jakarta.

Price, S. 2006. Patofisiologi Vol 1, Buku Kedokteran EGC, Jakarta.

Puspitorini, M. 2009. Cara Mudah Mengatasi Tekanan Darah Tinggi, Image Press, Yogyakarta.

Saraswati, S. 2009. Diet Sehat Untuk Penyakit Asam Urat, Diabetes, Hipertensi, dan stroke, A plus, Jogjakarta.

Soebroto, K. 2012. Aneka Resep Jus Buah Dan Sayuran Pembasmi Beragam Penyakit, Araska, Yogyakarta.

Kusnul Z \& Munir Z. 2012. Efek pemberian jus mentimun terhadap penurunan tekanan darah. 